О.Б. Леонтьєв, М.В. Науменко

Харківський національний університет Повітряних Сил ім. І. Кожедуба, Харків

\title{
МЕТОДИЧНИЙ ПІДХІД ДО РОЗВ'ЯЗУВАННЯ МАТЕМАТИЧНОЇ ЗАДАЧІ СИНТЕЗУ РАЦІОНАЛЬНОЇ ПРОГРАМИ РОЗВИТКУ СИСТЕМИ ОЗБРОЄННЯ ТАКТИЧНОЇ АВІАЦІЇ НА ОСНОВІ КРИТЕРІЮ ДОСЯГНЕННЯ МАКСИМАЛЬНО МОЖЛИВОГО РІВНЯ БОЙОВИХ СПРОМОЖНОСТЕЙ ЗА УМОВИ ОБМЕЖЕНОГО РЕСУРСНОГО ЗАБЕЗПЕЧЕННЯ
}

Задачу синтезу розвитку системи озброєння тактичної авіації в умовах можливої зміни у часі оперативного середовища та в межах призначених фінансових ресурсів та часових обмеженнях пропонується розв'язувати як задачу багатовекторної оптимізації, як пошук функиії розподілу за часом кількості нових літаків, щуо постачаються у війська з набуттям максимально можливого рівня спроможностей у виконанні покладених бойових завдань тактичною авіацією у відповідності до можливих сиенарїв застосування Повітряних Сил Збройних Сил України. Розглянуто можливі методичні підходи до розв'язання такого класу задач, а саме скалярізація критеріїв, пошук ефективних рішень, метод головного критерію та інші підходи. Обгрунтовано необхідність введення додаткового критерію придатності для подальших досліджень знайдених ефективних рімень задачі багатокритеріальної оптимізації.

Ключові слова: планування на основі спроможностей, критерії раціональності, науково-методичний апарат, оптимізація, раціональна програма розвитку, система озброєння тактичної авіацї Повітряних Сил Збройних Сил Украӥни.

\section{Вступ}

Постановка проблеми. В умовах сьогодення все більше загострення набуває прикладна проблема забезпечення Збройних Сил України, в тому числі, тактичної авіації Повітряних Сил (ПС) Збройних Сил (3С) України сучасними зразками озброєння та військової техніки (ОВТ). Прагнення України щодо зміцнення бойового потенціалу Збройних Сил України, в тому числі, шляхом оснащення новими, зокрема високотехнологічними зразками ОВТ та нарощування рівня боєготовності та боєздатності частин і підрозділів [1], стримується об'єктивно вимушеними обмеженнями військових витрат, обумовленими реальним економічним станом держави. Це актуалізує питання пошуку раціональних шляхів реалізації наявного матеріального та фінансового ресурсу держави при визначенні шляхів переоснащення військ новітньою ОВТ.

Реальний стан справ щодо технічного забезпечення бойовими літаками у авіації Повітряних Сил (ПС) Збройних Сил (ЗС) України, з одного боку, вимагає значної потреби у фінансовому ресурсі за умов обмежених ресурсних можливостей держави та конфлікту на Сході України, а з іншого боку - не дозволяє наділі відкладати на майбутнє проведення переозброєння авіаційних частин і підрозділів, враховуючи результати прогнозів зміни технічного стану наявних зразків озброєння і військової техніки, рівня військових загроз, що існують зараз та вини- катимуть у майбутньому. Об'єктивно, нажаль, держава не має достатніх ресурсів для задоволення усіх потреб ПС 3С України [2-6]. Зазначене протиріччя робить актуальним розробку відповідного методичного підгрунтя щодо обгрунтування або компромісних рішень по визначенню та реалізації пріоритетних напрямів розвитку озброєння і військової техніки тактичної авіації ПС ЗС України, метою якого було би набуття якщо не необхідного, то максимально можливого рівня спроможностей тактичною авіацією у виконанні завдань за визначеними сценаріями застосування, або рішення про відмову від певних воєнно-політичних амбіцій у повітряному просторі та спрямування ресурсів на забезпечення набуття пріоритетних спроможностей.

3 урахуванням перспектив розвитку безпекового середовища довкола України під час чергового оборонного огляду були ідентифіковані ключові ризики і загрози національній безпеці та ймовірні сценарії виникнення й розвитку ситуацій воєнного характеру на середньо- та довгострокову перспективи, 3 яких Візією Повітряних Сил 2035 зафіксовані функціональні групи спроможностей, які мають набути ПС ЗС України:

1) спроможності 3 ведення протиповітряної оборони;

2) наступальні, вогневі, транспортні та розвідувальні спроможності, які дозволять у разі збройного конфлікту завоювати у визначеному районі та на 
визначений час перевагу в повітрі, створюючи необхідні передумови для подальшого нанесення ураження противнику, здійснення повітряних перевезень, ведення повітряної розвідки та виконання інших завдань в інтересах об'єднаних сил;

3) спроможності, що забезпечують виконання Повітряними Силами Збройних Сил України завдань за призначенням, їх організаційну та технічну взаємосумісність із НАТО [7-8].

Аналіз останніх досліджень і публікацій. Вирішення системної проблеми набуття вказаних спроможностей ПС ЗС України має відбуватися 3 урахуванням, з одного боку, того, що наявні літаки тактичної авіації у найближчій перспективі вичерпають свій ресурс, а з іншого боку - на фоні зростаючого дефіциту фінансових ресурсів ускладнення виділення коштів для забезпечення закупівлі сучасних зразків бойової авіаційної техніки у необхідних обсягах для набуття всього переліку визначених спроможностей $[1 ; 5]$. Проблема обмеженості фінансування Збройних Сил України не перестає бути наболілою вже багато років, про що свідчить відсутність закупівель бойової авіаційної техніки [7; 11]. Все це надає підвищеної актуальності питанню розробки відповідних методичних підходів до обгрунтування раціональних шляхів забезпечення Збройних Сил, їх видів та родів військ новою ОВТ, особливо з врахуванням переходу оборонного планування України на євроатлантичні стандарти [4; 9-18].

В умовах ресурсних та часових обмежень неминучим стає питання вибору: у якому обсязі, у якому часовому інтервалі на періоді планування i які саме спроможності мають набуватися. 3 математичної точки зору, в такому випадку коректно вести мову про постановку та розв'язання задачі багатокритеріальної оптимізації при синтезі програми оновлення системи озброєння тактичної авіації. Але за оглядом доступних джерел науково-технічної інформації, наприклад, [10;12; 14-18], такого роду постановка задачі зустрічається лише тільки для формування кінцевої мети розвитку систем ОВТ виду (роду) військ ЗС України, зокрема кількісноякісного складу системи озброєння тактичної авіації, без, власне, постановки математичної задачі синтезу раціональної саме програми розвитку систем ОВТ видів (родів) військ. При цьому відсутні методичні підходи, які би забезпечували оцінювання безпосередньо впливу зміни кількісно-якісного складу системи ОВТ, зокрема, авіації ПС ЗС України на зміну спроможностей військ у виконанні завдань за різними сценаріями та з урахуванням змін оперативного середовища. Виключенням $є$ роботи [19-21], в яких за рахунок формалізації ефекту від застосування тактичної авіації ПС ЗС України за умови поступового оновлення парку бойових тактичних літаків шляхом застосування методу бойових потенціалів, враховується такий вплив, а також враховується вплив зміни оперативного середовища на значення необхідного для набуття рівня спроможностей авіаційних частин і підрозділів. В той же час, в даних роботах розроблено лише тільки методики або розв'язання математичних задач оптимізації, побудованих на основі критерію мінімізації витрат ресурсів при обмеженнях на рівень набутих спроможностей та часу, або критерію мінімізації часу набуття необхідних спроможностей, зведених до однієї цільової функції, тобто так званих однокритеріальних задач.

3 оглядом на вищенаведене метою статті $\epsilon$ розробка методичного підходу до розв'язання математичної задачі синтезу раціональної програми розвитку тактичної авіації на основі критерію досягнення максимально можливого рівня бойових спроможностей за умови обмеженого ресурсного забезпечення, поставленої у вигляді задачі багатокритеріальної оптимізації.

\section{Виклад основного матеріалу}

Розглянемо варіант стратегії переозброєння тактичної авіації ПС ЗС України, який може мати місце у разі неможливості реалізації інших стратегій, а саме стратегій сталого розвитку та швидкої ліквідації нестачі спроможності за мінімально можливий час, що описані в [19-21]. Стратегія сталого розвитку передбачає реалізацію програми розвитку системи ОВТ тактичної авіації ПС ЗС України на основі критерію мінімізації фінансових витрат за умови досягнення необхідних бойових спроможностей. Стратегія швидкої ліквідації нестачі спроможності передбачає за мінімально можливий час реалізацію програми виведення системи ОВТ тактичної авіації ПС ЗС України з кризового стану для ліквідації критичної нестачі наявних спроможностей та доведення їх до визначеного необхідного рівня у відповідних сценаріях застосування тактичної авіації у найкоротші терміни [19-20].

Найбільш критичним для реалізації програми переозброєння тактичної авіації може стати неможливість фінансового забезпечення досягнення необхідного рівня спроможностей для виконання всього спектру завдань за визначеними сценаріями застосування ПС ЗС України на заданій глибині планування переозброєння. Наслідком відсутності відповідного фінансування стане незабезпечення виконання термінів набуття заданого рівня спроможностей ПС Збройних Сил України [19-21].

За таких умов можливим шляхом підтримання боєздатності тактичної авіації ПС ЗС України може стати стратегія постійної ліквідації нестачі спроможностей вздовж всього періоду планування з вимушеним недосягненням ї необхідного рівня. При такій стратегії при обмеженому (недостатньому) 
фінансуванні на заданій глибині планування можна лише вести мову про досягнення найбільш можливого рівня (який може бути не достатнім) нарощування всіх спроможностей тактичної авіації ПС ЗС України, або забезпечення необхідного рівня виконання максимальної кількості завдань за визначеними пріоритетами.

Формалізований критерій раціональності програми розвитку системи озброєння авіації за стратегію постійної ліквідації нестачі спроможності вздовж всього періоду планування буде мати загальний вигляд [19]:

$$
\left\{\begin{array}{l}
\int_{t_{0}}^{T_{\text {зад }}} \sum_{j=1}^{n} K_{\text {БПij }} \sum_{r=1}^{R} \delta_{i j r} \dot{X}_{j r}(t) d t \rightarrow \max , \forall i=\overline{1, m} \\
\int_{t_{0}}^{T_{\text {зад }}} \sum_{j=1}^{n} C_{1 j} \sum_{r=1}^{R} \dot{X}_{r j}(t) d t \leq \int_{t_{0}}^{T_{\text {зад }}} \dot{S}_{\text {зад }}(t) d t, \forall j=\overline{1, n} \\
T_{\text {гот } i} \leq T_{\text {зад }},
\end{array}\right.
$$

де $n$ - кількість типів літальних апаратів, що $є$ доступними на світовому ринку озброєння для закупівлі та постачання у війська та складають сукупність альтернативних типів багатофункціональних винищувачів;

$m$ - загальна кількість бойових завдань, що визначені до виконання авіаційному угрупованню по всіх можливих сценаріях застосування тактичної авіації Повітряних Сил ЗС України;

$K_{\text {БПіј }}$ - значення коефіцієнту бойового потенціалу зразка $j$-го типу у вирішенні $i$-го завдання;

$\delta_{i j r}$ - символ, який характеризує можливість залучення засобів $j$-го типу до виконання $i$-го бойового завдання та інших бойових завдань із сукупності $m$ завдань водночас у відповідності до визначеної структури бойового потенціалу авіаційного угруповання ( $\delta_{i j r}=1-$ при можливості одним й тим же засобом $j$-го типу виконувати бойове завдання $i$-го типу водночас 3 завданням $r$-го типу, та $\delta_{i j r}=0$ - при неможливості цього);

$R$ - загальна кількість можливих варіантів розподілу наявної кількості бойових літаків по бойових завданнях, виставлене постановником задачі оптимізації в залежності від властивостей альтернативних типів багатофункціональних винищувачів, максимальне значення якої може дорівнювати числу розміщень значень символу $\delta_{i j r}(0$ або 1$)$ по кількості бойових завдань, включаючи варіанти залучення одних й тих же засобів до виконання всіх завдань, а також варіанту їх незалучення до виконання жодного з завдань $R_{\max }=A_{m}^{2}+2$;
$T_{\text {гот } i}$ - час набуття необхідного рівня спроможності тактичною авіацією у виконанні $i$-го бойового завдання;

$T_{\text {зад }}$ - заданий час набуття спроможностей по кожному з усіх $m$ визначених бойових завдань за всіма сценаріями і ситуаціями застосування тактичної авіації;

$$
\dot{X}_{j r}(t) \text { - невідома (яка підлягає визначенню в }
$$

ході розв'язування задачі оптимізаціі) похідна за часом функції кількості літаків $j$-го типу, що використовуються для набуття спроможностей у $r$-му завданні, та яку треба поставити у війська (темп оновлення парку за рахунок літаків даного $j$-го типу);

$C_{1 j}$ - вартість закупівлі одного серійного зразка літаків $j$-го типу;

$\dot{S}_{\text {зад }}(t)$ - функція розподілу за часом видатків оборонного бюджету на фінансування заходів з переозброєння тактичної авіації.

Перші $m$ виразів в (1) описують умову досягнення максимальної спроможності по всій кількості завдань, покладених на тактичну авіацію, за визначеними сценаріями застосування ПС Збройних Сил України при виділених обсягах ресурсів. Наступний вираз характеризує обмеження, що накладені на фінансові ресурси в кожен поточний момент часу $t$ на всій глибині планування.

Особливістю формалізованого критерію (1) $є$ те, що в ньому не вимагається набуття необхідного рівня спроможностей тактичною авіацією за всіма бойовими завданнями, а вимагається досягнення максимально можливого їх значення за рахунок оновлення бойового авіаційного парку в умовах обмеженого ресурсного забезпечення на визначеній глибині планування.

Розв'язання такої задачі у аналітичному вигляді пов'язане із суттєвими труднощами. До того ж, враховуючи той факт, що невідомі, які відшуковуються - кількість бойових літаків, які постачатимуться у військові частини у певний момент часу, за своїм фізичним змістом приймають суто дискретні, а саме позитивні цілі значення, для розв'язування поставленої математичної оптимізаційної задачі (1) доцільно здійснити перехід від інтегралів до інтегральних сум Рімана. Такий перехід реалізується шляхом розбиття періоду планування $\left[t_{0}, T_{\text {зад }}\right]$ на кінцеву кількість $T$ рівномірних відрізків - інтервалів, тривалістю $\Delta t$ кожен, тобто $T=\frac{T_{\text {зад }}-t_{0}}{\Delta t}$. При цьому, будемо вважати, що постачання нових літаків у війська на кожному інтервалі часу буде відбуватися у середині кожного інтервалу та нові літаки 
відразу після постачання у військові частини починають використовуватися за призначенням [20]. Тоді формалізований критерій раціональності програми (1) перетворюється у наступну систему виразів шляхом запису формалізованого критерію (1) у дискретному вигляді:

$$
\left\{\begin{array}{l}
\sum_{\tau=1}^{T} \sum_{j=1}^{n} K_{\text {БПij }} \sum_{r=1}^{R} \delta_{i j r} \Delta X_{j r \tau} \rightarrow \max , \forall i=\overline{1, m} ; \\
\sum_{\tau=1}^{T} \sum_{j=1}^{n} C_{1 j} \sum_{r=1}^{R} \Delta X_{j r \tau} \leq \sum_{\tau=1}^{T} S_{\tau}^{3 a d}, \forall j=\overline{1, n} ; \\
T_{\text {гот } i} \leq T_{\text {зад }} ; \\
\Delta X_{j \tau}=\sum_{r}^{R} \Delta X_{r j \tau} \leq \Delta N_{j \tau}^{\max } ; \forall j=\overline{1, n} ; \\
\Delta N_{j \tau}^{\max }=\min \left\{N_{j \tau}^{\text {наявн } \max }+\dot{N}_{j \tau}^{\max } \cdot \Delta t_{\tau} ;\left[\frac{S_{\tau}^{3 a d}}{C_{1 j}}\right]\right\},
\end{array}\right.
$$

де $\tau$ - поточний інтервал часу $\Delta t$;

$\Delta X_{r j \tau}$ - невідома (та, що відшуковується в задачі) кількість літаків $j$-го типу з усіх альтернативних типів літаків, що призначається до виконання сукупності завдань 3 урахуванням властивостей багатофункціональності даного типу літака, можливих для закупівлі та постачанню у війська на $\tau$-му інтервалі часу (кроці дискретного часу), така що:

$$
\Delta X_{r j \tau}=\dot{X}_{r j \tau} \Delta t_{\tau} \approx \frac{\Delta X_{r j \tau}}{\Delta t_{\tau}} \Delta t_{\tau}
$$

$\Delta N_{j \tau}^{\max }$ - максимально можлива кількість літаків $j$ го типу, які доступні для закупівлі на світовому ринку озброєння на інтервалі часу $\tau$;

$N_{j \tau}^{\text {наявн max }}$ - максимальна кількість літаків $j$-го типу, що вже виготовлені (наявні на ринку озброєння) та можуть бути закупленими (в тому числі, із застосуванням процедур лізингу) та поставленими у війська на $\tau$-му інтервалі часу;

$$
\dot{N}_{j \tau}^{\max } \text { - максимально можливий темп серійно- }
$$

го виробництва літаків $j$-го типу на $\tau$-му інтервалі часу;

$$
\left[\frac{S_{\tau}^{3 a d}}{C_{1 j}}\right]-\text { максимальна кількість літаків } j \text {-го }
$$

типу, що може бути закупленою на $\tau$-му інтервалі часу за фінансових обмежень $S_{\tau}^{3 а д, ~ в и з н а ч е н а ~} 3$ округленням до найменшої цілої величини.

3 математичної точки зору, як вже відмічалося, оптимізаційна задача синтезу раціональної програми розвитку системи озброєння авіації (2) відноситься до задач багатокритеріальної оптимізації, тобто до класу задач, що мають кілька цільових функцій. Метою розв'язання таких задач є знаходження рішення, яке в деякому сенсі є найкращим за всією сукупністю цільових функцій (часткових критеріїв).

Загальноприйнятими методичними підходами до розв'язання задач багатокритеріальної оптимізації $є$ [22-34]:

- згортання (скаляризація) часткових критеріїв, що дозволяє звести задачу багатокритеріальної оптимізації до задачі однокритеріальної оптимізації;

- метод головного критерію, у відповідності до якого визначається один головний критерій (цільова функція), за яким здійснюється оптимізація, а решта часткових критеріїв - переводяться до складу обмежень, що також зводить задачу багатокритеріальної оптимізації до задачі однокритеріальної оптимізації;

- послідовне розв'язання ряду однокритеріальних задач оптимізації, при цьому рішення, що були отримані на попередніх етапах, можуть бути засновані у якості обмежень;

- звуження множини альтернативних рішень, що розглядаються (цей підхід вимагає обгрунтування додаткових умов вибору оптимального рішення 3 цієї звуженої множини варіантів рішень);

- пошук альтернативного рішення, що має задані властивості.

Розглянемо більш детально вище перелічені методичні підходи, які найчастіше застосовуються на практиці.

Будемо вважати, що існує та вже знайдена множина допустимих рішень, що задовольняє обмеженням задачі оптимізації (1), яку позначимо $\left\{\dot{X}_{j r}(t)\right\}$. Для формування звуженої множини допустимих рішень задачі багатокритеріальної оптимізації застосовуються так звані ефективні рішення. В загальному вигляді рішення можуть бути [22; 25-26; 29; 32-34]:

- ефективними за Слейтером (слабо ефективні рішення, $\mathrm{S}(X))$ :

$$
\begin{gathered}
\forall \dot{X}_{j r}(t), \dot{X}_{j r}(t) \neq \dot{X}_{j r}^{*}(t): \\
P_{i}\left(\dot{X}_{j r}^{*}(t)\right)>P_{i}\left(\dot{X}_{j r}(t)\right), \forall i=\overline{1, m}, \forall r=\overline{1, R},
\end{gathered}
$$

де $\dot{X}_{j r}^{*}(t)$ - будь яке, окремо взяте значення похідної за часом кількості літаків з множини допустимих рішень (в межах виділеного фінансового ресурсу в поточний момент часу), при постачанні у війська якої забезпечується набуття тактичною авіацією приросту спроможності у виконанні $i$-го бойового завдання з бойовим потенціалом $P_{i}\left(\dot{X}_{j r}^{*}(t)\right)$ більшим, ніж при будь якому іншому значенні такої похідної $\dot{X}_{j r}(t)$ із сукупності допустимих рішень $P_{i}\left(\dot{X}_{j r}(t)\right)$.

Для того, щоб знайдене рішення багатокритеріальної задачі було ефективним за Слейтером, необ- 
хідно, щоб існував такий вектор значень максимально можливих набутих спроможностей (бойових потенціалів) тактичної авіації у виконанні усіх $m$ завдань, для якого при будь-якій зміні кількісноякісного складу парку літаків тактичної авіації (або зміні розподілу бойових літаків за задачами) вектор значень можливих набутих спроможностей за визначеними завданнями був би меншим, ніж цей вектор;

- ефективними за Парето $(P(X))$ :

$$
\begin{gathered}
\forall \dot{X}_{j r}(t), \dot{X}_{j r}(t) \neq \dot{X}_{j r}^{*}(t): \\
P_{i}\left(\dot{X}_{j r}^{*}(t)\right) \geq P_{i}\left(\dot{X}_{j r}(t)\right), \forall i=\overline{1, m}, \forall r=\overline{1, R},
\end{gathered}
$$

але

$$
\exists \dot{X}_{j r}^{*}(t): P_{i}\left(\dot{X}_{j r}^{*}(t)\right)>P_{i}\left(\dot{X}_{j r}(t)\right)
$$

що в термінах, задачі, що розглядається, може тлумачитися наступним чином: для того, щоб знайдене рішення багатокритеріальної задачі було ефективним за Парето, необхідно, щоб існував такий вектор значень максимально можливих набутих бойових потенціалів угрупованням тактичної авіації у виконанні усіх $m$ завдань, для якого при будь-якій зміні кількісно-якісного складу парку літаків тактичної авіації (або зміні розподілу бойових літаків за задачами) вектор значень можливих набутих спроможностей за визначеними завданнями був би не більшим цього вектору, але існувало би хоча б одне завдання, набутий потенціал у виконанні якого був би меншим, ніж до зміни кількісно-якісного парку літаків;

- ефективними по Смейлу (строго ефективні рішення, $\operatorname{Sm}(X))$ :

$$
\begin{gathered}
\forall \dot{X}_{j r}(t), \dot{X}_{j r}(t) \neq \dot{X}_{j r}^{*}(t): \\
P_{i}\left(\dot{X}_{j r}^{*}(t)\right) \geq P_{i}\left(\dot{X}_{j r}(t)\right), \forall i=\overline{1, m}, \forall r=\overline{1, R},
\end{gathered}
$$

що в термінах, задачі, яка розглядається, може тлумачитися в сенсі: для того, щоб знайдене рішення багатокритеріальної задачі було ефективним за Смейлом, необхідно, щоб існував такий вектор значень максимально можливих набутих спроможностей (бойових потенціалів тактичної авіації) у виконанні усіх покладених $m$ бойових завдань, для якого при будь-якій зміні кількісно-якісного складу парку літаків тактичної авіації (або зміні розподілу бойових літаків за задачами) вектор значень можливих набутих спроможностей за визначеними завданнями був би або меншим, або дорівнював попередньому значенню.

Цілком очевидно, що розглянуті множини допустимих рішень мають відношення $\operatorname{Sm}(X) \subset P(X) \subset S(X)$.

Стосовно вибору методу побудови ефективних рішень, нажаль, в доступній науковій літературі не наводиться доказова база щодо переваг приведених методичних підходів для застосування при розв'язуванні різноманітних за своєю природою типів прикладних задач. Також залишається дискусійним положення щодо аргументації пріоритетності вибору компромісних рішень саме із множини оптимальних рішень за Парето. Може мати місце лише припущення, що зазвичай компромісними рішеннями вважаються рішення із множини ефективних рішень за Парето, при якому на множині ефективних рішень ОПР може визначитися після відповіді на запитання “на скільки можна поступитися приростом бойового потенціалу за якоюсь однією задачею задля компенсації набуття бойового потенціалу за іншою задачею, не виходячи за рамки накладених ресурсних обмежень”. Це обумовлює необхідність формування або додаткової схеми пошуку компромісів для даної конкретної прикладної задачі, або виставлення додаткових умов оцінювання ступеню придатності знайдених рішень для подальшого застосування, наприклад, введення додаткового критерію придатності ефективних рішень або критерію їх порівняльного оцінювання.

Так, виходячи 3 положень теорії багатокритеріальної оптимізації, пошук оптимального рішення може завершитися обиранням не лише одного варіанту рішення, а цілого набору рішень, що є підмножиною множини допустимих рішень. Згідно основних принципів розв'язання оптимізаційних задач, наприклад, принципу Еджворта-Парето, вибір найкращого рішення має робитися серед елементів множини Парето [24-33]. Іншими словами, надаючи перевагу одному Парето-оптимальному рішенню над іншими Парето-оптимальними рішеннями, ОПР вимушена прийняти деякий компроміс, що призведе до деякого погіршення рішення хоча б за одним критерієм (але при цьому, обов'язково отримує покращення хоча б за якимось іншим критерієм).

Таким чином, найсуттєвішим недоліком застосування поняття Парето-оптимального рішення для розв'язання практичних задач оптимального вибору $\epsilon$ те, що воно, як правило, не дозволяє знайти єдиного рішення задачі, а дає можливість отримати лише певну множину ефективних (в розумінні конкретної ОПР) рішень.

Скаляризація в контексті багатокритеріальної оптимізації включає широкий клас алгоритмів, що дозволяють для будь-якої багатокритеріальної задачі побудувати таку однокритеріальну задачу, щоб іiі глобальний оптимум був або Парето-оптимальним рішенням, або ефективним за Слейтером для вихідної задачі оптимізації. Привабливість такого підходу цілком виправдана - для розв'язання скаляризованої оптимізаційної задачі можна застосовувати практично будь-який з широко відомих численних і добре апробованих методів розв'язання однокритеріальних 
задач. Більш того, додатковою практичною перевагою є те, що більшість способів скаляризації можуть бути застосовані безпосередньо людиною при постановці математичної задачі оптимізації, без спеціального програмного забезпечення. Це дозволяє вирішувати багатокритеріальні задачі за допомогою, фактично, будь-якого доступного засобу оптимізації. 3 оглядом на різноманіття способів скаляризації, варто провести подальшу класифікацію всередині даного підходу.

Для скаляризації задачі багатокритеріальної оптимізації найбільш часто використовуються методи згортки критеріїв шляхом застосування [25; $29-$ 31; 33-34]:

- адитивних функцій

$$
F(X)=\sum_{i=1}^{m} \alpha_{i} f_{i}(X), \forall i=\overline{1, m},
$$

де $\alpha_{i}$ - вектор вагових коефіцієнтів, що відображають відносну важливість кожного 3 критеріїв $\alpha\left(\alpha_{1}, \alpha_{2}, \ldots \alpha_{m}\right), \sum_{i=1}^{m} \alpha_{i}=1 ;$

- мультиплікативних функцій

$$
F(X)=\prod_{i=1}^{m} \alpha_{i} f_{i}(X), \forall i=\overline{1, m},
$$

- мінімізації максимального значення, так званої згортки Гермейера:

$$
\Gamma_{\alpha}(X)=\max _{i=1, m} \alpha_{i} f_{i}(X) .
$$

Застосування адитивної згортки, у відповідності до теореми Карліна [22; 30-34], забезпечує знаходження множини рішень задачі багатокритеріальної оптимізації, що будуть оптимальними за Парето. Вибір конкретного елемента множини Парето може відповідати набору коефіцієнтів важливості критеріїв, особистої переваги ОПР, або вимагатиме застосування додаткових математичних методів звуження множини Парето.

Застосування згортки Гермейера (9) дозволяє знайти рішення багатокритеріальної задачі, яке буде оптимальним за Слейтером [32-33]:

$$
\Gamma_{\alpha}(X) \rightarrow \min .
$$

В загальному випадку при виборі варіанту згортки критеріїв при розв'язанні багатокритеріальної задачі оптимізації доцільно керуватися наступним [24-27; 31-34]:

- адитивна згортка найбільш застосована у випадку розв'язання задач, для вирішення яких принципове важливе значення мають абсолютні значення альтернативних критеріїв;

- мультиплікативну згортку доцільно обирати тоді, коли важливими є зміни абсолютних значень альтернативних критеріїв при варіюванні вхідними даними;

- згортку Гермейера, або мінімаксний (максиміний) підхід, доцільно застосовувати тоді, коли важливим є досягти зрівняння нормованих значень суперечливих критеріїв (цільових функцій).

Але слід зазначити, що розглянуті способи розв'язання задачі багатокритеріального вибору досить прості в ідейному відношенні, але на жаль, не витримують критики з позицій сучасного рівня розвитку теорії прийняття багатокритеріальних рішень. Перш за все, відомим $є$ факт, що обгрунтування точного визначення вагових коефіцієнтів критеріїв не існує [29; 31-34]. Дослідники, що використовують лінійну згортку, нерідко вважають коефіцієнти згортки такими, що задають ступінь впливу окремих критеріїв на остаточний вибір (остаточну, або зведену оцінку): чим більше коефіцієнт, тім більший пріоритет має відповідний йому критерій. Експерт або ОПР, вибираючи конкретні значення зазначених коефіцієнтів для будь-якої з наведених згорток, буде виходити зі свого власного уявлення про ці коефіцієнти, оскільки немає доказового підгрунтя щодо оцінювання і чисельного висловлювання у формі коефіцієнтів ступеню впливу окремих критеріїв на остаточну оцінку. Це обумовлено тим, що дослідження характеру зміни точки умовного максимуму лінійної згортки в залежності від іiі коефіцієнтів складає предмет теорії параметричної оптимізації, i частіше за все, є досить складним обчислювальним завданням. Крім того, на різних множинах можливих варіантів точки умовного максимуму однієї і тієї ж лінійної згортки, в загальному випадку, різні. Це свідчить про неспроможність оцінювання впливу коефіцієнтів для однієї і тієї ж ОПР, яка використовує один й теж самий набір критеріїв для різних множин допустимих рішень.

Аналіз останніх досліджень показує, що “об'єктивного”, єдиного для всіх ОПР, поняття важливості критеріїв не існує, оскільки кожен суб'єкт має право вкладати в цей термін свій власний сенс. Причому, цей сенс навіть у одного і того ж суб'єкта може змінюватися за часом або в залежності від особливості самої задачі вибору, що розв'язується, та/або існуючих обставин. Тому будь-яка спроба введення визначення важливості критеріїв $є$ ні чим іншим, як “штучною” спробою відображення ОПР особистих уявлень про важливість тих або інших критеріїв [26; 31-34].

Метод лінійної згортки відноситься до класу евристичних підходів, які не мають строгого обгрунтування, що при його практичному застосуванні може призвести до не найкращих остаточних варіантів вибору. Останнє підтверджується і тим, що до теперішнього часу не існує доказової бази, що в тому чи іншому класі задач багатокритеріального вибору застосування саме методу лінійної згортки га- 
рантовано призводить до “найкращого” (в тому чи іншому сенсі) результату. Тим не менш, основною перевагою застосування скаляризації $є$ можливість зведення багатокритеріальних оптимізаційних задач до однокритеріальних.

Оскільки в практичній задачі синтезу раціональної програми розвитку системи ОВТ тактичної авіації ПС ЗС України, що розглядається, важливими $є$ саме абсолютні значення критеріїв (цільових функцій), тобто значення максимально можливого набутого бойового потенціалу у реалізації всіх $m$ бойових задач в межах виділеного фінансового ресурсу у визначений час, то найбільш раціональним буде застосування адитивної згортки. Але для подальшого аналізу за всіма максимально можливими набутими спроможностями (набутим бойовим потенціалом) у виконанні всіх визначених завдань, у випадку обмеженого ресурсного забезпечення адитивна згортка (як і будь яка інша) є малоінформативною. Це обумовлено неможливістю оцінювання скаляризованого вектору з точки зору диференційованого аналізу набутих спроможностей за всіма задачами та, власне, неможливістю, без введення додаткових процедур, здійснити оцінювання (у кількісному вимірі) - наскільки критичним $є$ їх недосягнення, якщо таке матиме місце.

3 огляду доцільності застосування адитивної згортки виду (7) математична задача синтезу раціональної програми розвитку системи озброєння тактичної авіації на основі критерію досягнення максимально можливого рівня бойових спроможностей за умови обмеженого ресурсного забезпечення (2) прийме вигляд:

$$
\left\{\begin{array}{l}
\sum_{i=1}^{m} \alpha_{i} \cdot \sum_{\tau=1}^{T} \sum_{j=1}^{n} K_{\text {БПij }} \sum_{r=1}^{R} \delta_{i j r} \Delta X_{j r \tau} \rightarrow \max \\
\sum_{\tau=1}^{T} \sum_{j=1}^{n} C_{1 j} \sum_{r=1}^{R} \Delta X_{j r \tau} \leq \sum_{\tau=1}^{T} S_{\tau}^{3 a d}, \forall j=\overline{1, n} ; \\
T_{\text {готi }} \leq T_{\text {зад }} ; \\
\Delta X_{j \tau}=\sum_{r}^{R} \Delta X_{r j \tau} \leq \Delta N_{j \tau}^{\max }, \forall j=\overline{1, n} ; \\
\Delta N_{j \tau}^{\max }=\min \left\{N_{j \tau}^{\text {наявн } \max }+\dot{N}_{j \tau}^{\max } \cdot \Delta t_{\tau} ;\left[\frac{S_{\tau}^{3 a \partial}}{C_{1 j}}\right]\right\},
\end{array}\right.
$$

де $\alpha_{i}$ - вектор вагових коефіцієнтів, що відображають відносну важливість кожного 3 критеріїв $\alpha\left(\alpha_{1}, \alpha_{2}, \ldots \alpha_{m}\right), \sum_{i=1}^{m} \alpha_{i}=1$.

Для визначення вагових коефіцієнтів може бути застосований метод аналізу ієрархій [25], що дозволить отримати оцінки ступеню важливості набуття спроможностей тактичної авіації у виконанні визначених $m$ задач. Однак, такий підхід не має строго доказового підгрунтя [25; 33]. Це пов'язане 3 неминучим суб'єктивізмом проведення експертних процедур оцінювання переваг часткових критеріїв.

Доречно зауважити, що методичний підхід до розв'язання задач багатокритеріальної оптимізації методом головного критерію (цільової функції) може розглядатися як окремий випадок скаляризації 3 визначенням для пріоритетної цільової функції вагового коефіцієнту, рівного 1, решта, відповідно буде дорівнювати нулю.

Зведення багатокритеріальної задачі оптимізації до однокритеріальної за рахунок введення адитивної згортки цільових функцій усуває логічні складності і залишає лише обчислювальні процедури розв’язання однокритеріальної задачі оптимізації. Але залишається дискусійним обгрунтованість такого підходу, оскільки при проведенні аналізу застосування адитивної згортки основним його недоліком $€$ взаємна компенсація часткових критеріїв. Це означає, що зменшення одного з критеріїв аж до нульового значення може бути компенсовано зростанням іншого критерію. Для ослаблення цього недоліку можуть бути введені спеціальні обмеження щодо мінімальних значень часткових критеріїв, вагових коефіцієнтів та інші способи [33].

Розв'язання багатокритеріальної задачі синтезу раціональної програми розвитку системи ОВТ тактичної авіації ПС Збройних Сил України в умовах обмеженого фінансування має відбуватися у нерозривній ув'язці із оцінюванням можливих результатів реалізації набутих спроможностей тактичної авіації. Оскільки набуття спроможностей реалізовуватиметься в умовах обмеженого фінансування та жорстких часових інтервалах, прямий вибір раціонального шляху оновлення бойової авіаційної техніки, навіть, при сформованій множині Парето- оптимальних рішень, може бути не очевидним, що вимагатиме додаткового оцінювання альтеративних шляхів набуття необхідних спроможностей.

3 математичної точки зору розглянуті методи розв'язання багатокритеріальних задач оптимізації виглядають як такі, що можуть дати рішення, але постає наступне запитання: чи відповідає знайдене рішення - набутий кількісно-якісний склад парку нових літаків тактичної авіації та можливий їх розподіл за визначеними $m$ завданнями - необхідному рівню спроможностей тактичної авіації для досягнення цілей iї застосування у визначених сценаріях застосування Збройних Сил України? Для відповіді на це запитання вбачається за необхідне введення додаткового критерію придатності знайденого рішення.

В загальному вигляді методичний підхід до розв'язування математичної задачі синтезу раціональної програми розвитку системи озброєння тактичної авіації на основі критерію досягнення максима- 
льно можливого рівня бойових спроможностей за умови обмеженого ресурсного забезпечення можна представити наступним чином.

На першому етапі здійснюється формування початкових даних, в результаті чого визначаються:

1) перелік бойових завдань тактичної авіації, які потрібно вирішувати $i=\overline{1, m}$, порядок їх виконання та зміна нестачі кожної зі спроможностей за часом на протязі визначеного терміну глибини планування $\Delta P_{i}\left(T_{\text {зад }}\right)$, як різниця між необхідним та часткою наявного на початок терміну планування бойового потенціалу тактичної авіації у виконанні відповідного бойового (оперативного) завдання [19];

2) перелік альтернативних варіантів типів бойових літаків $j=\overline{1, n}$, за рахунок постачання яких планується нарощувати спроможності у виконанні завдань та значення основних узагальнених показників їх бойових властивостей, а саме - коефіцієнтів бойового потенціалу у виконанні відповідних бойових завдань $\left\{K_{Б П i j}\right\}$, вартості закупівлі одного серійного виробу $\left\{C_{1 j}\right\}$, максимального темпу серійного виробництва $\dot{N}_{j \tau}^{\max }$ та/або кількості наявних на ринку озброєння серійних виробів літаків кожного 3 обраних альтернативних типів $\left\{N_{j \tau}^{\text {наявн } \max }\right\}$;

3) варіанти розподілу наявної сукупності літаків кожного 3 альтернативних типів по завданнях 3 урахуванням їх ступеню багатофункціональності (можливістю одного й того ж літака водночас виконувати різні за сутністю бойові завдання, наприклад в одному бойовому вильоті протистояти винищувачам противника та наносити удари по наземних цілях, тощо), тобто матриця символів $\left\{\delta_{i j r}\right\}$;

4) розподіл по роках на всій глибині планування заданих обсягів ресурсів у коштовно-грошовому вигляді (видатків держави), що можуть бути виділеними на оновлення парку бойових літаків тактичної авіації $S^{3 а д}(t)$;

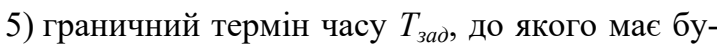
ти реалізоване набуття спроможностей для виконання завдань у відповідності до визначених сценаріїв застосування тактичної авіації за рахунок оновлення бойової авіаційної техніки.

На другому етапі формуються цільові функції математичної задачі багатокритеріальної оптимізації, для яких вимагається максимізація набуття спроможностей, за всіма завданнями, які має виконувати тактична авіація, а також обмежень, поперше, щодо фінансового ресурсу, який може бути виділений на переозброєння тактичної авіації ПС ЗС України, по-друге, щодо часу набуття необхідного рівня спроможностей;

На наступному етапі ОПР має зробити вибір, яким методом буде розв'язуватися задача багатокритеріальної оптимізації. 3 огляду на доцільність застосування адитивної згортки, знову ж ОПР визначатиметься 3 методом знаходження вагових коефіцієнтів для часткових критеріїв. Після застосування адитивної згортки здійснюється зведення багатокритеріальної задачі оптимізації до однокритеріальної, яка буде являти собою задачу лінійного програмування, розв'язання якої можливе широко відомими та апробованими практикою методами, наприклад таким, як симплекс-метод.

Результатом розв'язання зведеної до однокритерільної задачі буде розподіл кількості нових літаків кожного типу по інтервалах часу, які треба закупити та поставити у війська для набуття максимально можливих спроможностей за всіма бойовими завданнями з урахуванням раціонального розподілу наявної кількості нових літаків по бойових завданнях у відповідності із їх ступенем багатофункціональності в межах виділеного фінансового ресурсу та часового обмеження набуття спроможностей.

В постановці математичної задачі синтезу раціональної програми розвитку системи озброєння тактичної авіації на основі критерію досягнення максимально можливого рівня бойових спроможностей за умови обмеженого ресурсного забезпечення в явному вигляді не представлено, яким чином можна оцінити придатність знайденого рішення, тобто його відповідність (або невідповідність) рівню необхідних спроможностей, які мали бути досягнуті. Хоча слід відзначити, що знайдене рішення буде відповідати вимогам оптимальності та вимогам обмежень, тобто задача буде розв'язана та оптимальне рішення знайдене. Але з урахуванням сфери застосування отриманого рішення, не менш актуально постає питання на скільки, власне, $є$ оптимальним знайдене рішення, тобто досягнуто чи ні необхідного рівня спроможностей у виконанні завдань відповідно до сценаріїв застосування тактичної авіації ПС ЗС України. Це обумовлює необхідність проведення оцінювання знайденого рішення за критерієм придатності.

В методичному підході, що розроблюється, в якості критерію придатності пропонується обирати вектор, компоненти якого характеризують ступінь набуття спроможності тактичною авіацією по кожному 3 покладених бойових завдань, яка кількісно оцінюється набутим, за рахунок постачання нових літаків у війська бойовим потенціалом $P_{i}^{\text {наб }}\left(T_{\text {зад }}\right)$ у відповідному бойовому завданні, що може бути реалізованим, у порівнянні з відповідним необхідним рівнем спроможності в даному бойовому завданні на визначений час $\Delta P_{i}\left(T_{\text {зад }}\right)$ : 


$$
\begin{aligned}
& P_{i}^{\text {наб }}\left(T_{\text {зад }}\right)=\sum_{\tau=1}^{T} \sum_{j=1}^{n} K_{\text {БПij }} \sum_{r=1}^{R} \delta_{i j r} \Delta X_{j r \tau} \\
& P_{i}^{\text {наб }}\left(T_{\text {зад }}\right) \geq \Delta P_{i}\left(T_{\text {зад }}\right), \forall i=\overline{1, m},
\end{aligned}
$$

де $\Delta X_{j r \tau}-$ знайдене в результаті розв'язування задачі багатокритеріальної оптимізації рішення.

У випадку, якщо критерій (12) виконується для всіх покладених задач, то знайдене рішення дозволяє набути тактичною авіацією необхідного рівня спроможностей. В протилежному випадку, ступінь недосяжності необхідних спроможностей може бути кількісно оціненою різницею між правою та лівою частиною виразу (12) по кожному бойовому завданню, що покладаються на тактичну авіацію.

Таке оцінювання дає підстави для системного і детального аналізу по всім задачам щодо виявлення тих 3 них, за якими необхідний рівень спроможностей досягнутий, або не досягнутий, і наскільки критичним $є$ таке недосягнення заданого рівня спроможностей. За результатами такого аналізу, зокрема, у випадку недосяжності заданих рівнів спроможностей за всіма задачами, ОПР може приймати рішення щодо розв'язання багатокритеріальної задачі методом головного критерію з визначенням пріоритетної цільової функції - пріоритетної задачі, набуття спроможностей для виконання якої $є$ критичним - та переведенням решти цільових функцій до складу обмежень, або методом послідовного визначення пріоритетних для набуття необхідних спроможностей у окремих бойових задачах, при цьому рішення, що були отримані на попередніх етапах, можуть застосовуватися у постановці повторної математичної задачі оптимізації в якості обмежень.

Можливий варіант вибору пріоритетного набуття тих спроможностей, для яких час реалізації набуття необхідного бойового авіаційного парку буде найменшим, або тих, що вимагатимуть найменших фінансових витрат. Також, як альтернативний, може розглядатися шлях набуття спроможностей, якщо пріоритетними вважати ті бойові завдання, які мають найменше відхилення від необхідного їх рівня. У такому разі, набуття деяких спроможностей може досягти необхідного рівня.

Альтернативним варіантом визначення пріоритетними у набутті спроможності бойовими завданнями у відповідності до можливих сценаріїв засто- сування тактичної авіації ПС ЗС України можуть бути ті, реалізація яких є найрезультативнішою або 3 точки зору ефекту, або ресурсовитратності або оперативності.

За результатами всебічного аналізу альтернативних шляхів оновлення бойового авіаційного парку тактичної авіації цілком ймовірна ситуація, за якої $є$ неможливим досягнення необхідного рівня спроможностей (або за причини недостатнього фінансування, або за причини неможливості оновлення парку бойової авіаційної техніки у зв'язку із відсутністю можливості проведення тендерних процедур та, власне, закупівлі бойових літаків). В такому випадку ОПР може прийняти рішення або щодо корегування фінансового ресурсу, призначеного на розвиток тактичної авіації шляхом формування обгрунтованого запиту до Державного бюджету України, або ініціювати залучення фінансової допомоги міжнародних партнерів, або здійснити перегляд переліку спроможностей тактичної авіації та вимог до них.

\section{Висновки}

Таким чином, розроблено методичний підхід до розв'язання математичної задачі синтезу раціональної програми розвитку тактичної авіації на основі критерію досягнення максимально можливого рівня бойових спроможностей за умови обмеженого ресурсного забезпечення, поставленої у вигляді задачі багатокритеріальної оптимізації.

Для вирішення поставленої багатокритеріальної задачі оптимізації обгрунтовано доцільність застосування адитивної згортки та зведення iï до однокритеріальної задачі. Також обгрунтовано необхідність введення додаткового критерію придатності знайденого оптимального рішення задачі, а саме оцінювання відповідності максимально можливих набутих спроможностей тактичною авіацією у виконанні визначених бойових завдань їх необхідному рівню. Наведене вище дає підстави вважати поставлену мету статті досягнутою.

Подальші дослідження будуть спрямовані на розробку методичних рекомендацій щодо інтерпретації результатів розв'язування задачі синтезу в можливих на практиці різних сполученнях вихідних даних.

\section{Список літератури}

1. Указ Президента України №392/2020 “Про рішення Ради національної безпеки і оборони України від 14 вересня 2020 року "Про Стратегію національної безпеки України". - Режим доступу: https://www.president.gov.ua/documents/3922020-35037.

2. Указ Президента України від 04.06.2016 року № 240/2016 "Про рішення Ради національної безпеки і оборони України від 20.05.2016 "Про Стратегічний оборонний бюлетень України". - Режим доступу: https://www.president.gov.ua/documents/2402016-20137.

3. Офіційний сайт Міністерства оборони України. Рекомендації з оборонного планування на основі спроможностей. - Режим доступу: https://www.mil.gov.ua/content/other/ Recommendationson_CBP_120617.pdf. 
4. Чепков І.Б. Новітня стратегія національної безпеки України введена в дію: на черзі оновлення воєнної та військово-технічної політики / І.Б. Чепков, В.В. Зубарєв, В.П. Тютюнник // Озброєння та військова техніка. - 2020. - № 3(27). - C. 3-12.

5. ЗРК середньої дальності для ППО України: створити чи придбати? - Режим доступу: https://armyinform.com.ua/2020/12/zrk-serednoyi-dalnosti-dlya-ppo-ukrayiny-stvoryty-chy-prydbaty/.

6. Жданов С.В. Проблема заміни парку бойових літаків у Україні / С.В. Жданов // Озброєння та військова техніка. - 2016. - № 4(2). - С. 9-16.

7. Візія Повітряних Сил 2035. - Вінниця: Командування Повітряних Сил Збройних Сил України. - 2020. - 42 с.

8. Єдиний перелік (каталог) спроможностей Міністерства оборони України, Збройних Сил України та інших складових сил оборони (затвердж. Міністром оборони України від 09.12.2019 № 7983/в/36.). - К.: Міністерство оборони України, 2019. - $618 \mathrm{c.}$

9. Теорія озброєння. Науково-технічні проблеми та завдання. Т. 5. Воєнно-технічна політика України: формування, стан та шляхи удосконалення: монографія / І.Б. Чепков, В.В. Зубарєв, В.О. Смірнов [та ін.]. - К.: ВД Дмитра Бураго, 2017. - 448 с.

10. Методичний підхід до формування оптимального варіанту програмних заходів з оснащення авіації збройних сил літальними апаратами / О.С. Мавренков, В.В. Логінов, В.В. Войтенко, С.В. Кирнажицький // Наука і техніка Повітряних Сил Збройних Сил України - 2016. - № 1(22). - С. 46-49.

11. Мавренков О.С. До питання оцінювання заданого рівня бойового потенціалу авіації Збройних Сил України / O.Є. Мавренков, С.І. Леженін // Збірник наукових праць Державного науково-дослідного інституту авіації. - 2011. № 14. - C. 16-22.

12. Чепков І.Б. Основні аспекти методології формування та супроводження реалізації середньострокових програм озброєння в умовах особливого періоду / І.Б. Чепков, М.І. Луханін, І.В. Борохвостов // Озброєння та військова техніка. 2016. - № 4(2). - С. 3-8.

13. Оборонна реформа: системний підхід до оборонного менеджменту: монографія / А. Павліковський, В. Фролов, Ф. Саганюк та ін.; за заг. ред. А. Сиротенка. - Київ: НУОУ, 2020. - 274 с.

14. Оборонний огляд: український вимір 2014 -2018: монографія / Ф. Саганюк, А. Павліковський, П. Щипанський та ін.; за заг. ред. І. Руснака. - Київ: МО та ГШ ЗС України, НУОУ, 2019. - 196 с.

15. Борохвостов І.В. Визначення критеріїв та методів оцінювання шляхів забезпечення військових формувань озброєнням та військовою технікою / І.В. Борохвостов, М.О. Білокур // Озброєння та військова техніка. - 2018. № 3(19). - С. 3-8.

16. Бадрак В.В. Переозброєння Збройних Сил України: раціоналізація підходів, пошук альтернативних шляхів / В.В. Бадрак // Озброєння та військова техніка. - 2016. - № 1(9). - С. 3-8.

17. Чепков І.Б. Основні аспекти методології формування та супроводження реалізації середньострокових програм озброєння в умовах особливого періоду / І.Б. Чепков М.І. Луханін, І.В. Борохвостов // Озброєння та військова техніка. 2016. - № 4(2). - С. 3-8.

18. Офіційний сайт Міністерства оборони України. Рекомендації з оборонного планування на основі спроможностей. - Режим доступу: https://www.mil.gov.ua/content/other/ Recommendationson_CBP_120617.pdf.

19. Дроздов С.С. Формалізовані критерії раціональності програми розвитку системи озброєння тактичної авіації Повітряних Сил Збройних Сил України на довгостроковій перспективі / С.С. Дроздов, О.Б. Леонтьєв, М.В. Науменко // Збірник наукових праць ХНУПС. - 2020. - № 3(65). - C. 13-24. https://doi.org/10.30748/zhups.2020.65.02.

20. Дроздов С.С. Методичний підхід до розв'язування математичної задачі синтезу раціональної програми розвитку системи озброєння тактичної авіації на основі критерію мінімізації фінансових витрат за умови досягнення необхідних бойових спроможностей / С.С. Дроздов, О.Б. Леонтьєв, М.В. Науменко // Наука і техніка Повітряних Сил Збройних Сил України. - 2020. - № 4(41). - С. 54-63. https://doi.org/10.30748/nitps.2020.41.06.

21. Леонтьєв О.Б. Напрями удосконалення науково-методичного апарату обгрунтування основних напрямів розвитку системи озброєння авіації Повітряних Сил Збройних Сил України / О.Б. Леонтьєв, М.В. Науменко // Наука і техніка Повітряних Сил Збройних Сил України. - 2020. - № 3(40). - С. 69-78. https://doi.org/10.30748/nitps.2020.40.08.

22. Канторович Л.В. Математико-экономические работы / Л.В. Канторович. - Новосибирск: Наука, 2011. - 760 с.

23. Кини Р.Л. Принятие решений при многих критериях: предпочтения и замещения / Р.Л. Кини, Х. Райфа. - М.: Радио и связь, 1981. -560 с.

24. Ларичев О.И. Теория и методы принятия решений / О.И. Ларичев. - М.: Логос, 2000. — 392 с.

25. Ногин В.Д. Принятие решений при многих критериях / В.Д. Ногин. - СПб.: Ютас, 2007. - 104 с.

26. Ногин В.Д. Сужение множества Парето: аксиоматический поход / В.Д. Ногин. - М.: Физматлит, 2016. - 249 с.

27. Овчаренко Ю.С. Формулювання математичної моделі багатокритеріального вибору військової техніки та результатів оцінки точності розв'язання задачі багатовекторної оптимізації / Ю.С. Овчаренко // Автомобільний транспорт. -2011 . № 29. - C. 71-75.

28. Моисеев Н.Н. Методы оптимизации / Н.Н. Моисеев, Ю.П. Иванилов, Е.М. Столяров. - М.: Наука, 1978. -358 с.

29. Штойер Р. Многокритериальная оптимизация. Теория, вычисления и приложения: Пер. с англ. - М.: Радио и связь, 1992. $-504 \mathrm{c:}$

30. Воронин А. Компромисс и консенсус в теории принятия решений / A. Воронин // International Journal "Information Theories and Applications". - 2013. - Vol. 20. - No. 4. - P. 323-330.

31. Ногин В.Д. Линейная свертка критериев в многокритериальной оптимизации / В.Д. Ногин // Искусственный интеллект и принятие решений. - 2014. - № 4. - С. 73-82.

32. Лотов А.В. Многокритериальные задачи принятия решений / А.В. Лотов, И.И. Поспелова. - М.: МАКС Пресс, 2008. - $197 \mathrm{c}$. $-288 \mathrm{c}$.

33. Брахман Т.Р. Многокритериальность и выбор альтернативы в технике / Т.Р. Брахман. - М.: Радио и связь, 1984.

34. Шатохина Н.В. Анализ подходов к решению многокритериальной задачи поиска вариантов развития предприятия / Н.В. Шатохина, Е.М. Реутова // Открытые информационные и компьютерные интегрированные технологии. -2009. - № 42. - С. 179-184. 


\section{Відомості про авторів:}

Леонтьєв Олексій Борисович доктор технічних наук професор головний науковий співробітник Харківського національного університету Повітряних Сил ім. І. Кожедуба, Харків, Україна https://orcid.org/0000-0003-4003-7759

\section{Науменко Марина Володимирівна} кандидат технічних наук старший науковий співробітник докторант

Харківського національного університету

Повітряних Сил ім. І. Кожедуба,

Харків, Україна

https://orcid.org/0000-0002-1216-9263
Information about the authors:

Oleksii Leontiev

Doctor of Technical Sciences Professor

Chief Research

of Ivan Kozhedub Kharkiv

National Air Force University,

Kharkiv, Ukraine

https://orcid.org/0000-0003-4003-7759

\section{Maryna Naumenko}

Candidate of Technical Sciences Senior Research

Doctoral Student

of Ivan Kozhedub Kharkiv

National Air Force University,

Kharkiv, Ukraine

https://orcid.org/0000-0002-1216-9263

\title{
МЕТОДИЧЕСКИЙ ПОДХОД К РЕШЕНИЮ МАТЕМАТИЧЕСКОЙ ЗАДАЧИ СИНТЕЗА РАЦИОНАЛЬНОЙ ПРОГРАММЫ РАЗВИТИЯ СИСТЕМЫ ВООРУЖЕНИЯ ТАКТИЧЕСКОЙ АВИАЦИИ НА ОСНОВЕ КРИТЕРИЯ ДОСТИЖЕНИЯ МАКСИМАЛЬНО ВОЗМОЖНОГО УРОВНЯ БОЕВЫХ ВОЗМОЖНОСТЕЙ В УСЛОВИЯХ ОГРАНИЧЕННОГО РЕСУРСНОГО ОБЕСПЕЧЕНИЯ
}

\author{
А.Б. Леонтьев, М.В. Науменко
}

Задачу синтеза развития системы вооружения тактической авиации в условиях возможного изменения во времени оперативной обстановки и в пределах выделенных финансовых ресурсов и временных ограничениях предлагается решать как задачу многовекторной оптимизачии, как поиск функиии распределения по времени количества новых самолетов, поставляемых в войска, с приобретением максимально возможного уровня выполнения возложенных боевых задач тактической авиачией в соответствии с возможными сиенариями применения Воздушных Сил Вооруженных Сил Украины. Рассмотрены возможные методические подходы к решению такого класса задач, а именно скаляризачия критериев, поиск эффективных решений, метод главного критерия и другие подходы. Обоснована необходимость введения дополнительного критерия оценки пригодности для дальнейших исследований найденных эффективных решений задачи многокритериальной оптимизации.

Ключевые слова: планирование на основе возможностей, критерии рачиональности, научно-методический аппарат, оптимизачия, рациональная программа развития, система вооружения авиации Воздушных Сил Вооруженных Сил Украины.

SOLUTION METHODICAL APPROACH TO MATHEMATICAL PROBLEMS SYNTHESIS OF RATIONAL DEVELOPMENT PROGRAMS OF ARMS TACTICAL AIRCRAFT BASED ON CRITERIA ACHIEVE THE HIGHEST POSSIBLE LEVEL OF COMBAT BUILDING IN TERMS LIMITED RESOURCES

O. Leontiev, M. Naumenko

The methodical approach to solving the problem of synthesis of the program of tactical aviation armament system development in modern conditions, characterized on the one hand - extremely insufficient level of funding from the State Budget of Ukraine program, measures for development, purchase, modernization of armaments and military equipment of the Air Force Ukraine, on the other hand - the impossibility of ensuring the acquisition (maintenance) of certain capabilities of the Air Force of the Armed Forces of Ukraine to fend off potential threats in the airspace of Ukraine, which may be a problem in connection with the depletion of operational a resources of combat aircraft. The problem of synthesis of tactical aviation weapon system development in the conditions of possible change in time of operational environment and within the appointed financial resources and time constraints is offered to be solved as a problem of multi-vector optimization of acquisition of the maximum possible level of capabilities in performing tactical aviation tasks of the Armed Forces of Ukraine. Possible methodological approaches to solving this class of problems are considered, namely, scalarization of criteria, search for effective solutions, the method of the main criterion and other approaches. The necessity of introduction of additional criterion of estimation of suitability for further researches of the found effective decisions of a problem of multicriteria optimization is substantiated. An analysis of the feasibility of applying a particular approach to solving the optimization problem. The solution of the problem will be a function of time distribution of the type and number of aircraft to be delivered to aviation units, which will be procured in conditions of insufficient funding, and which should ensure the acquisition of maximum tactical aviation capabilities of the Air Force of Ukraine.

Keywords: capability-based planning, rationality criteria, scientific and methodological apparatus, optimization, rational development program, System of the Air Force of the Armed Forces of Ukraine. 